\title{
Hydrological seasons fast identification applied to Jaitêua and São Lourenço lakes, Manacapuru, Amazonas State
}

\section{Identificação rápida de períodos hidrológicos aplicada aos lagos Jaitêua e São Lourenço, Manacapuru, estado do Amazonas}

\author{
Heitor Thury Barreiros Barbosa ${ }^{1 *} \&$ Maria Gercilia Mota Soares ${ }^{2}$ \\ ${ }^{1}$ Instituto Federal de Educação, Ciência e Tecnologia do Amazonas- Ifam \\ ${ }^{2}$ Instituto Nacional de Pesquisas da Amazônia (Inpa/CBIO) \\ *Email: hthury@gmail.com
}

Recebido: 11 de dezembro de 2016 / Aceito: 13 de julho de 2017/ Publicado: 14 de dezembro de 2017

\begin{abstract}
This paper approaches the application of Hydrological Seasons Fast Identification procedure, proposed by Bittencourt \& Amadio (2007), to floodplain lakes with no hydrometric history. For this, we used the correlation between the Solimões river water level, from January 1972 to December 2015, and the Jaitêua and São Lourenço lakes depths, collected from July 2006 to June 2007. Besides the usual results, seasons limits and its intensity and duration classes, we spotted differences between the river and lakes hydrological seasons, a phenomena normally associated with the environments connectivity. Most importantly, we would like to stimulate the debates about arbitraries and the development of better methodological standards for Amazon floodplains seasons identifications.
\end{abstract}

Keywords: Amazon, floodplain, hydrology, seasons.

\begin{abstract}
Resumo Esse artigo aborda a aplicação da Identificação Rápida de Períodos Hidrológicos, procedimento proposto por Bittencourt \& Amadio (2007), à lagos de várzea sem histórico hidrométrico. Para isso, usamos a correlação entre a cota linimétrica do rio Solimões, de 01/1972 a 12/2015, e a profundidade dos lagos Jaitêua e São Lourenço, medida entre 07/2006 e 06/2007. Além dos resultados habituais, limítrofes e suas classificações de intensidade e duração, foram observadas diferenças entre os períodos hidrológicos do rio e dos lagos, fenômeno normalmente associado ao tipo de conectividade entre os ambientes. Mais importante, gostaríamos de estimular os debates sobre a arbitrariedade e o desenvolvimento de melhores padrões metodológicos para identificação dos períodos hidrológicos na várzea.
\end{abstract}

Palavras-chave: Amazônia, estações, hidrologia, várzea. 


\section{Introduction}

Floodplain areas are marked by high biodiversity and habitat heterogeneity, as well as sensitivity to environmental changes (Bayley, 1995; Junk \& Wantzen, 2004; Soares, Freitas \& Oliveira, 2014). They are also a scenario for complex relationships of animals, plants and the environment (Isaac, Fabre, Silva, Ruffino \& Saint-Paul, 2012). Effects of these environmental changes include the alteration of habitats, shifts in nutrient cycling patterns, and changes in temperature, oxygen levels, and other limnological variables (Kreibich, 2002; Esteves, 2011a; Almeida et al., 2014; Brito, Alves \& Espirito-Santo, 2014). Under the influence of the environmental variation, many organisms, namely ichthyofauna, suffer direct effects of changes in community composition and food availability (Poff et al., 1997; Winemiller \& Jepsen, 1998; Saint-Paul et al., 2000; Santos, Ferreira \& Amadio, 2008).

Despite its importance, Amazon floodplain seasons delimitation are mostly arbitrary (Merona \& Gascuel, 1993; Cunico, Graça, Veríssimo \& Bini, 2002; Maciel, 2010; Maciel, Soares \& Prestes, 2011), leading to comparison difficulties among different years studies. In attempt to establish a standard method, Bittencourt \& Amadio (2007) proposed a statistical procedure to identify the Negro river hydrological seasons based in its a water level historical dataset. The aim of this paper is to demonstrate how this procedure can be extended to lakes without any hydrological history, such as Jaitêua and São Lourenço lakes, part of Grande lake system, next to Manacapuru city, Amazonas State.

\section{Materials and Methods}

The depth of Jaitêua (coordinates S 3.28 W 60.72) and São Lourenço (coordinates S 3.24 W 60.75) lakes were measured monthly, from July 2006 to June 2007, always in the same location, using a metric tape with a sinker. The water level history for the Solimões River were obtained from the National Water Agency Hydrological Information System. We used the data from the hydrometric station code 14100000 (S 3.31 W 60.61), the closest to the lakes. This data set range from January 1972 to December 2015, totalizing 44 years of multiple daily measures. For the next analyses, we preferred the measures labeled as consistent and, for the data without it, the daily averages.

Firstly, to identify the Solimões River hydrological seasons, following the procedure described on Bittencourt \& Amadio (2007), we used the averages and standard deviations of the minimum and maximum annual water level to estimate the dry season limit (the average minimum level plus its standard deviation) and the flood season limit (the average maximum level minus its standard deviation).

Secondly, based on the limits above, the seasons could be classified as Low water (when the water level is below or equal the dry season limit), Rising water (when the water level is ascending between the dry and flood limits), High water (when the water level is above or equal the flood season limit) and Receding water (when the water level is descending between the dry and flood limits).

Thirdly, to classify the seasons intensity, we used the confidence interval $(\alpha=0,05)$ of the minimum and maximum annual water level. Thus, the Low water seasons were classified as weak (when the minimum water level of the year is above the confidence limits), strong (when the minimum water level of the year is below the confidence limits) or typical. Similarly, the High water seasons were classified as weak (when the maximum water level of the year is below the confidence limits), strong (when the maximum water level of the year is above the confidence limits) or typical.

Fourthly, to classify the seasons duration, we by its confidence interval $(\alpha=0,05)$, instead of the standard deviation as proposed by Bittencourt \& Amadio (2007). We had to exclude the years when water level does not reached the dry or the flood season limit, since it was difficult to distinguish Rising and Receding water seasons. Thus, the four seasons were classified as short (when the duration was below the confidence limits), long (when the duration was above the confidence limits) or typical.

Lastly, to identify the hydrological seasons of the lakes, we used regression analysis (Nelder \& Wedderburn, 1972; Hoffmann, 2016) to correlate its depths, measured from July 2006 to June 2007 as mentioned above, with the Solimões river water level. Thus, we could predict the lakes dry and flood season limits from the river's.

Distributions normality were verified by Shapiro-Wilk test (Yap \& Sim, 2011; Noughabi \& Arghami, 2011). All the analyses described above were supported by the R statistical software (R Core Team, 2017). 


\section{Results}

Solimões river minimum and maximum annual water level were, respectively, $8.53 \pm 2.03$ and $18.91 \pm$ $1.07 \mathrm{~m}(\mathrm{n}=44)$. Thus, we estimated the dry and flood season limits as 10.56 and $17.84 \mathrm{~m}$, respectively, and classified the hydrological periods according to Table 1. The duration of the low, rising, high and receding water seasons were, respectively, $72.86 \pm 30.13,131.72 \pm 27.44,98.10 \pm 31.12$ and $62.55 \pm 16.69$ days $(\mathrm{n}=$ 29). Through the confidence intervals, the seasons intensity and duration were classified according to Table 2. Normality assumption was valid for the maximum annual water level $(p=0.7228, n=44)$, but not for the minimum ( $\mathrm{p}=0.0409, \mathrm{n}=44)$, as seen on Figure 1, and for the low, rising and high water season duration ( $\mathrm{p}$ $>0.1177, \mathrm{n}=29)$, excepting the receding water $(\mathrm{p}=0.0366, \mathrm{n}=29)$, as seen on Figure 2.

Table 1. Solimões river hydrological seasons delimitation

\begin{tabular}{ll}
\hline \multicolumn{1}{c}{ Season } & \multicolumn{1}{c}{ Water level } \\
\hline Low water & Below or equal 10.56 m \\
Rising water & Ascending between 10.56 and $17.84 \mathrm{~m}$ \\
High water & Above or equal 17.84 m \\
Receding water & Descending between 17.84 and $10.56 \mathrm{~m}$ \\
\cline { 3 - 3 }
\end{tabular}

Table 2. Solimões river seasons intensity and duration classes

\begin{tabular}{|c|c|c|c|}
\hline \multirow[b]{2}{*}{ Season } & \multicolumn{3}{|c|}{ Intensity } \\
\hline & Weak & Typical & Strong \\
\hline Low water & Above $9.13 \mathrm{~m}$ & Between 7.93 and $9.13 \mathrm{~m}$ & Below $7.93 \mathrm{~m}$ \\
\hline \multirow[t]{3}{*}{ High water } & Below $18.60 \mathrm{~m}$ & Between 18.60 and $19.23 \mathrm{~m}$ & Above $19,23 \mathrm{~m}$ \\
\hline & \multicolumn{3}{|c|}{ Duration } \\
\hline & Short & Typical & Long \\
\hline Low Water & Less than 61 days & Between 61 and 84 days & More than 84 days \\
\hline Rising Water & Less than 121 days & Between 121 and 142 days & More than 142 days \\
\hline High Water & Less than 86 days & Between 86 and 110 days & More than 110 days \\
\hline Receding Water & Less than 56 days & Between 56 and 69 days & More than 69 days \\
\hline
\end{tabular}

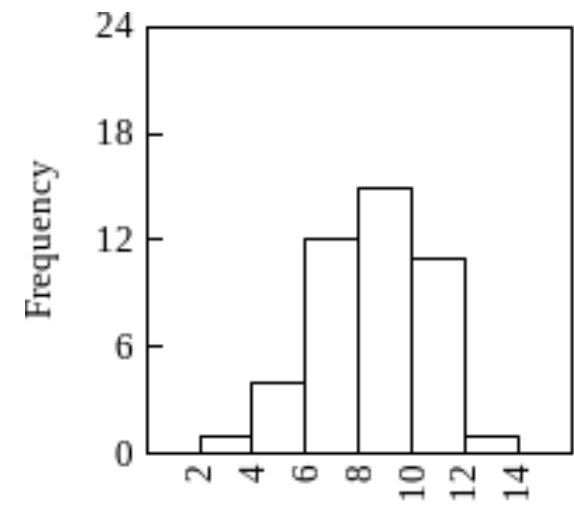

Min imum annual level (m)

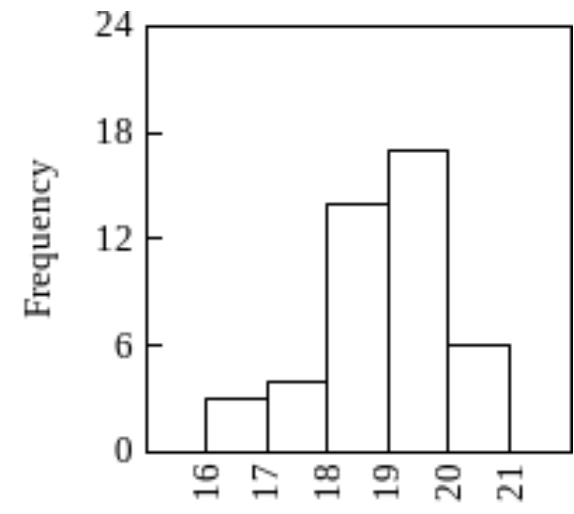

Maximum annual level (m)

Figure 1. Histogram of the Solimões river minimum and maximum annual water level

The correlation between the lakes depths and Solimões river water level produced the linear models described by Equations $1\left(\mathrm{r}^{2}=0.8081, \mathrm{p}=0.0002, \mathrm{n}=11\right)$ and $2\left(\mathrm{r}^{2}=0.9268, \mathrm{p}<0.0001, \mathrm{n}=9\right)$. The dispersion plots can be seen on Figure 3. Applying the Solimões river season limits, 10.56 and $17.84 \mathrm{~m}$, on these equations we estimated the dry and flood season limits for the Jaitêua lake, 2.23 and $6.40 \mathrm{~m}$, and for the São Lourenço lake, 3.49 and $7.71 \mathrm{~m}$. By these limits, we could define the hydrological periods as seen in Table 3. Although these equations cannot predict the seasons duration, it can be used to classify the seasons intensity, applying the Solimões river confidence limits (see Table 2), as shown in Table 4. 
$Z_{\text {Jai }}=0.5715 \cdot h_{\text {Sol }}-3.8022$

$Z_{\text {Lou }}=0.5791 \cdot h_{\text {Sol }}-2.6274(2)$

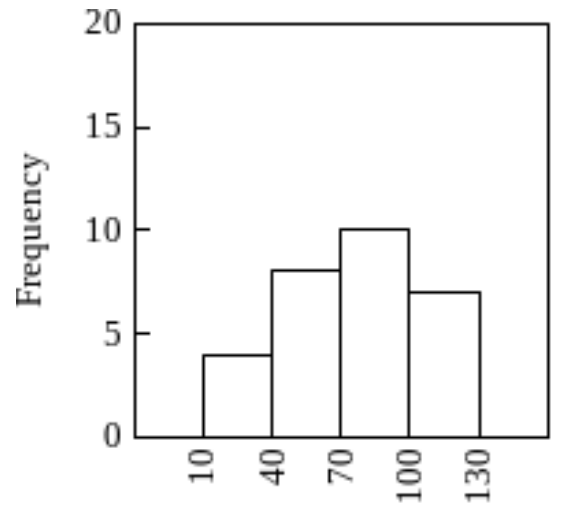

Low water duration (days)

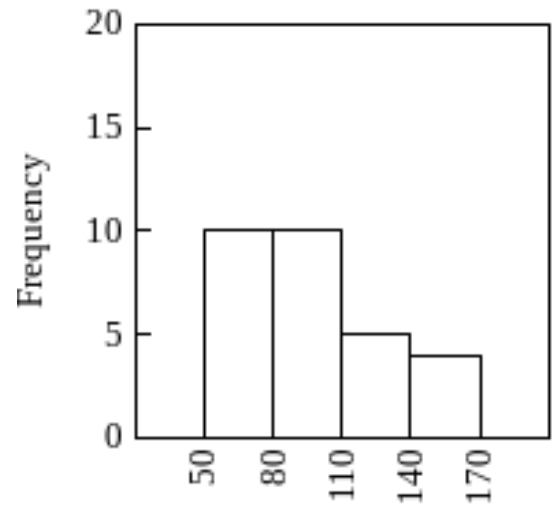

High water duration (days)
When:

$Z_{j a i}$ is the Jaitêua lake depth, in meters

$Z_{\text {lou }}$ is the São Lourenço lake depth, in meters

$h_{s o l}$ is the Solimões river water level, in meters

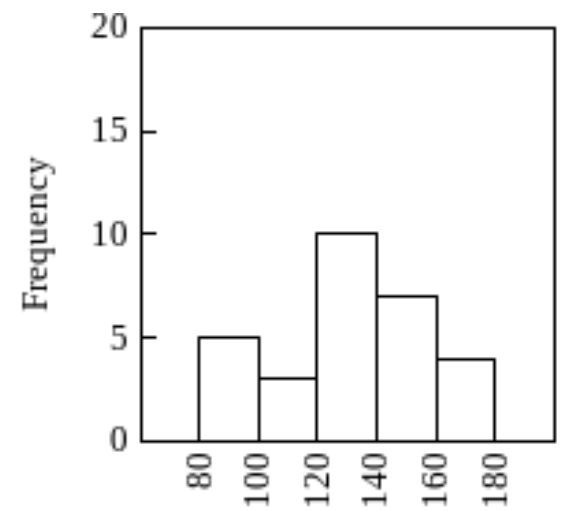

Rising water duration (days)

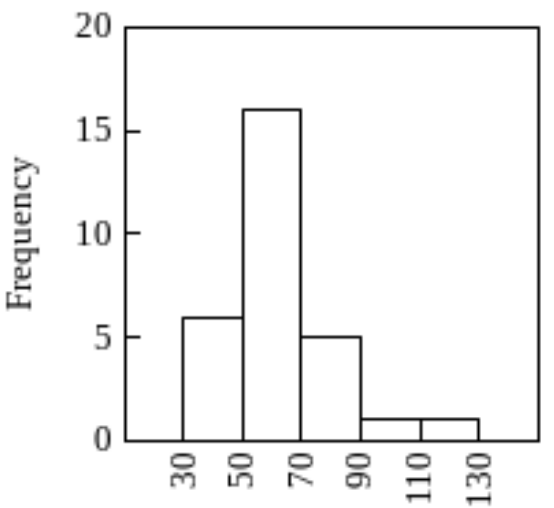

Receding water duration (days)

Figure 2. Histogram of the Solimões river seasons duration
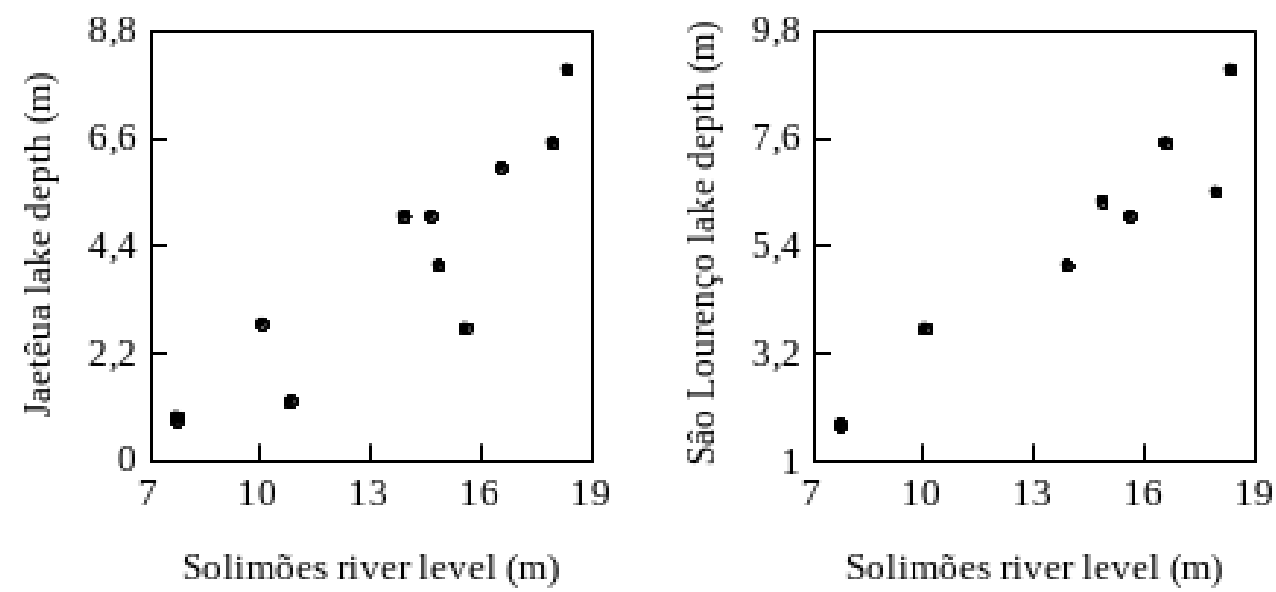

Figure 3. Dispersion plot of the correlation between Jaitêua and São Lourenço lakes depth and Solimões river water level 
Acta of Fisheries and Aquatic Resources

Table 3. Jaitêua and São Lourenço lakes hydrological seasons delimitation

\begin{tabular}{lcl}
\hline Lake & Season & \multicolumn{1}{c}{ Water level } \\
\hline Jaitêua & Low water & Below or equal $2.23 \mathrm{~m}$ \\
& Rising water & Ascending between 2.23 and $6.40 \mathrm{~m}$ \\
& High water & Above or equal $6.40 \mathrm{~m}$ \\
& Receding water & Descending between 6.40 and $2.23 \mathrm{~m}$ \\
\hline São Lourenço & Low water & Below or equal $3.49 \mathrm{~m}$ \\
& Rising water & Ascending between 3.49 and $7.71 \mathrm{~m}$ \\
& High water & Above or equal $7.71 \mathrm{~m}$ \\
& Receding water & Descending between 7.71 and $3.49 \mathrm{~m}$ \\
\hline
\end{tabular}

Table 4. Jaitêua and São Lourenço lakes seasons intensity classes

\begin{tabular}{ccccc}
\hline \multirow{2}{*}{ Lake } & & \multicolumn{3}{c}{ Intensity } \\
\cline { 4 - 5 } & Season & Weak & Typical & Strong \\
\hline Jaitêua & Low Water & Above $1.41 \mathrm{~m}$ & Between 0.73 and $1.41 \mathrm{~m}$ & Below 0.73 m \\
& High Water & Below $6.83 \mathrm{~m}$ & Between 6.83 and $7.19 \mathrm{~m}$ & Above 7.19 m \\
\hline \multirow{2}{*}{ São Lourenço } & Low Water & Above $2.66 \mathrm{~m}$ & Between 1.96 and $2.66 \mathrm{~m}$ & Below $1.96 \mathrm{~m}$ \\
& High Water & Below $8.14 \mathrm{~m}$ & Between 8.14 and $8.51 \mathrm{~m}$ & Above $8.51 \mathrm{~m}$ \\
\hline
\end{tabular}

Superposing Solimões river and the lakes season limits, we produced the Figure 4 to illustrate the differences of the water fluctuation between the environments. Table 5 presents the monthly seasons delimitation, during July 2006 and June 2007. Here we note some differences in the environments seasons: compared to Solimões river, Low water season starts earlier in Jaitêua lake and is shorter in São Lourenço lake. We can also see that São Lourenço lake does not reach the flood season limit in 2007.

Figure 4. Annual water level fluctuation of Jaitêua and São Lourenço lakes (continuous lines) and Solimões River (dashed lines)
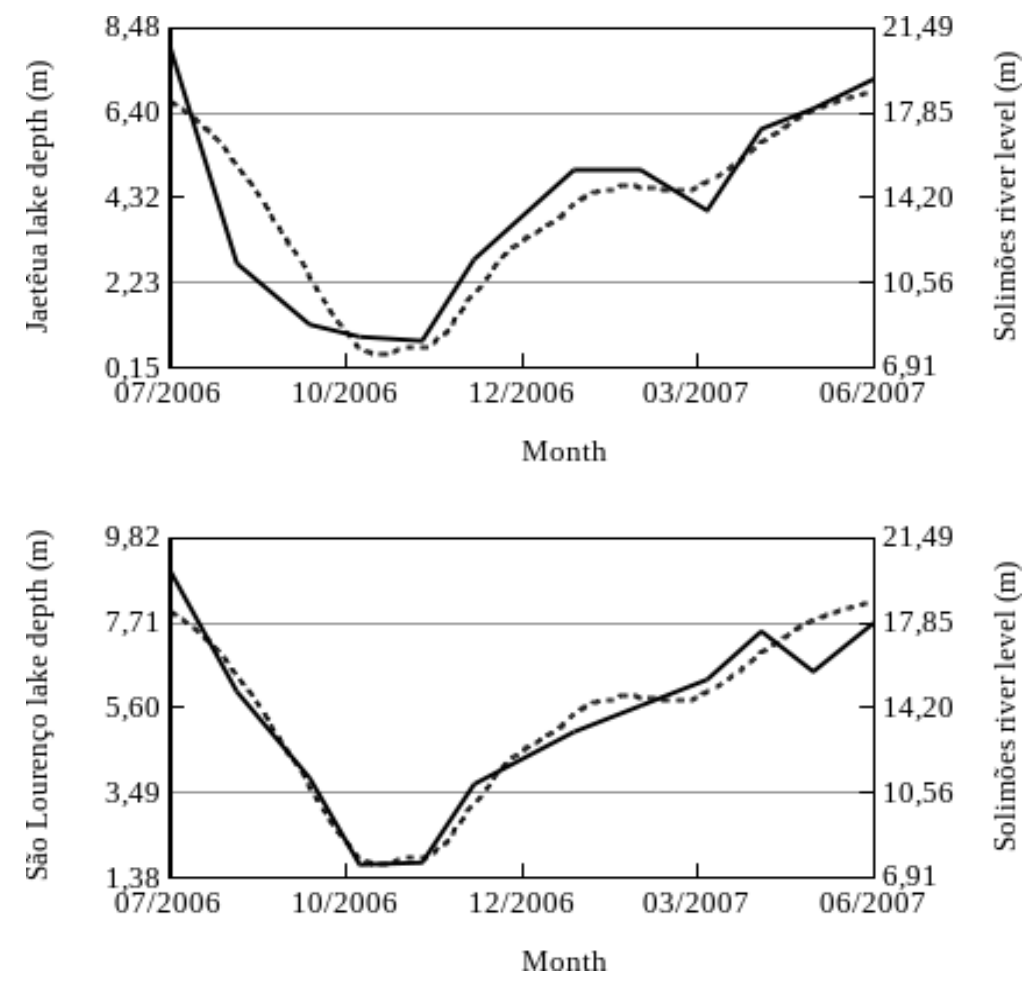

Table 5. Solimões River and Jaitêua and São Lourenço lakes monthly seasons

\begin{tabular}{lcccccccccccc}
\hline & \multicolumn{1}{c}{2006} & \multicolumn{1}{c}{2007} \\
\cline { 2 - 12 } Environment & Jul & Aug & Sep & Oct & Nov & Dec & Jan & Feb & Mar & Apr & Mai & Jun \\
\hline Solimões & Hi & Re & Re & Lo & Lo & Lo & Ri & Ri & Ri & Ri & Hi & Hi \\
Jaitêua & Hi & Re & Lo & Lo & Lo & Ri & Ri & Ri & Ri & Ri & Hi & Hi \\
São Lourenço & Hi & Re & Re & Lo & Lo & Ri & Ri & Ri & Ri & Ri & Ri & Ri \\
\hline
\end{tabular}

Hi: High water season; Re: Receding water season; Lo: Low water season; Ri: Rising water season 
Acta of Fisheries and Aquatic Resources

Finally, Table 6 summarizes the annual minimum and maximum water levels, seasons intensity and duration classes for Solimões River.

Table 6. Solimões River annual seasons intensity and duration classes

\begin{tabular}{|c|c|c|c|c|c|c|c|c|c|c|c|c|}
\hline \multirow[b]{2}{*}{ Year } & \multicolumn{4}{|c|}{$\begin{array}{l}\text { Season } \\
\text { intensity }\end{array}$} & \multicolumn{8}{|c|}{$\begin{array}{c}\text { Season } \\
\text { duration }\end{array}$} \\
\hline & $\begin{array}{r}\text { Low } \\
\text { water }\end{array}$ & & $\begin{array}{l}\text { High } \\
\text { water }\end{array}$ & & $\begin{array}{l}\text { Low } \\
\text { water }\end{array}$ & & $\begin{array}{r}\text { Rising } \\
\text { water }\end{array}$ & & $\begin{array}{l}\text { High } \\
\text { water }\end{array}$ & & $\begin{array}{c}\text { Receding } \\
\text { water }\end{array}$ & \\
\hline $1972 *$ & 10,66 & $\mathrm{We}$ & 19,23 & $\mathrm{St}$ & & & & & & & & \\
\hline $1973 *$ & 11,45 & $\mathrm{We}$ & 19,22 & Ty & & & & & & & & \\
\hline $1974 *$ & 12,51 & We & 19,09 & Ty & & & & & & & & \\
\hline 1975 & 10,03 & $\mathrm{We}$ & 19,72 & $\mathrm{St}$ & 23 & $\mathrm{~S}$ & 136 & $\mathrm{~T}$ & 135 & $\mathrm{~L}$ & 71 & $\mathrm{~L}$ \\
\hline 1976 & 8,84 & Ty & 19,99 & $\mathrm{St}$ & 66 & $\mathrm{~T}$ & 118 & $\mathrm{~S}$ & 127 & $\mathrm{~L}$ & 55 & $\mathrm{~S}$ \\
\hline $1977 *$ & 11,15 & We & 19,09 & Тy & & & & & & & & \\
\hline $1978 *$ & 10,95 & We & 18,75 & Ty & & & & & & & & \\
\hline 1979 & 7,89 & $\mathrm{St}$ & 18,7 & Ty & 102 & $\mathrm{~L}$ & 96 & $\mathrm{~S}$ & 70 & $\mathrm{~S}$ & 97 & $\mathrm{~L}$ \\
\hline $1980 *$ & 8,45 & Тy & 16,27 & We & & & & & & & & \\
\hline $1981 *$ & 7,74 & St & 17,45 & $\mathrm{We}$ & & & & & & & & \\
\hline 1982 & 8,76 & Тy & 19,44 & $\mathrm{St}$ & 57 & $\mathrm{~S}$ & 150 & $\mathrm{~L}$ & 95 & $\mathrm{~T}$ & 63 & $\mathrm{~T}$ \\
\hline $1983^{*}$ & 7,48 & $\mathrm{St}$ & 17,13 & $\mathrm{We}$ & & & & & & & & \\
\hline 1984 & 9,91 & $\mathrm{We}$ & 18,57 & $\mathrm{We}$ & 59 & $\mathrm{~S}$ & 156 & $\mathrm{~L}$ & 73 & $\mathrm{~S}$ & 78 & $\mathrm{~L}$ \\
\hline $1985^{*}$ & 10,3 & $\mathrm{We}$ & 16,6 & We & & & & & & & & \\
\hline 1986* & 11,81 & We & 18,59 & $\mathrm{We}$ & & & & & & & & \\
\hline 1987 & 8,49 & Ty & 18,63 & Тy & 79 & $\mathrm{~T}$ & 138 & $\mathrm{~T}$ & 69 & $\mathrm{~S}$ & 79 & $\mathrm{~L}$ \\
\hline 1988 & 8,26 & Ty & 18,33 & We & 72 & $\mathrm{~T}$ & 179 & $\mathrm{~L}$ & 54 & $\mathrm{~S}$ & 61 & $\mathrm{~T}$ \\
\hline 1989 & 9,38 & $\mathrm{We}$ & 19,94 & $\mathrm{St}$ & 11 & $\mathrm{~S}$ & 100 & $S$ & 140 & $\mathrm{~L}$ & 114 & $\mathrm{~L}$ \\
\hline 1990 & 6,7 & $\mathrm{St}$ & 18,57 & $\mathrm{We}$ & 93 & $\mathrm{~L}$ & 126 & $\mathrm{~T}$ & 79 & $\mathrm{~S}$ & 67 & $\mathrm{~T}$ \\
\hline 1991 & 6,83 & $\mathrm{St}$ & 18,62 & Ty & 85 & $\mathrm{~L}$ & 140 & $\mathrm{~T}$ & 77 & $\mathrm{~S}$ & 63 & $\mathrm{~T}$ \\
\hline $1992 *$ & 8,28 & Ty & 16,23 & $\mathrm{We}$ & & & & & & & & \\
\hline 1993 & 10,05 & $\mathrm{We}$ & 19,55 & $\mathrm{St}$ & 20 & $\mathrm{~S}$ & 157 & $\mathrm{~L}$ & 114 & $\mathrm{~L}$ & 74 & $\mathrm{~L}$ \\
\hline 1994* & 11,01 & We & 19,79 & $\mathrm{St}$ & & & & & & & & \\
\hline $1995 *$ & 5,52 & $\mathrm{St}$ & 17,77 & $\mathrm{We}$ & & & & & & & & \\
\hline 1996 & 9,41 & $\mathrm{We}$ & 19,11 & Ty & 51 & $\mathrm{~S}$ & 167 & $\mathrm{~L}$ & 90 & $\mathrm{~T}$ & 58 & $\mathrm{~T}$ \\
\hline 1997 & 4,95 & $\mathrm{St}$ & 19,52 & $\mathrm{St}$ & 107 & $\mathrm{~L}$ & 103 & $\mathrm{~S}$ & 107 & $\mathrm{~T}$ & 48 & $\mathrm{~S}$ \\
\hline 1998 & 5,57 & St & 18,28 & $\mathrm{We}$ & 110 & $\mathrm{~L}$ & 149 & $\mathrm{~L}$ & 50 & $\mathrm{~S}$ & 56 & $\mathrm{~T}$ \\
\hline 1999 & 7,49 & $\mathrm{St}$ & 20,03 & $\mathrm{St}$ & 93 & $\mathrm{~L}$ & 96 & $\mathrm{~S}$ & 132 & $\mathrm{~L}$ & 44 & $\mathrm{~S}$ \\
\hline 2000 & 8,58 & Ty & 19,14 & Ty & 53 & $\mathrm{~S}$ & 137 & $\mathrm{~T}$ & 93 & $\mathrm{~T}$ & 83 & $\mathrm{~L}$ \\
\hline 2001 & 7,44 & $\mathrm{St}$ & 18,86 & Ty & 82 & $\mathrm{~T}$ & 122 & $\mathrm{~T}$ & 96 & $\mathrm{~T}$ & 65 & $\mathrm{~T}$ \\
\hline 2002 & 8,01 & Ty & 19,56 & $\mathrm{St}$ & 41 & $\mathrm{~S}$ & 158 & $\mathrm{~L}$ & 109 & $\mathrm{~T}$ & 57 & $\mathrm{~T}$ \\
\hline 2003 & 9,86 & $\mathrm{We}$ & 19,02 & Тy & 41 & $\mathrm{~S}$ & 178 & $\mathrm{~L}$ & 90 & $\mathrm{~T}$ & 56 & $\mathrm{~T}$ \\
\hline $2004 *$ & 10,22 & $\mathrm{We}$ & 17,58 & $\mathrm{We}$ & & & & & & & & \\
\hline 2005 & 5,08 & $\mathrm{St}$ & 18,72 & Тy & 113 & $\mathrm{~L}$ & 127 & $\mathrm{~T}$ & 65 & $\mathrm{~S}$ & 60 & $\mathrm{~T}$ \\
\hline 2006 & 7,48 & $\mathrm{St}$ & 19,27 & $\mathrm{St}$ & 82 & $\mathrm{~T}$ & 137 & $\mathrm{~T}$ & 86 & $\mathrm{~T}$ & 60 & $\mathrm{~T}$ \\
\hline 2007 & 8,08 & Ty & 18,76 & Ty & 73 & $\mathrm{~T}$ & 161 & $\mathrm{~L}$ & 75 & $\mathrm{~S}$ & 56 & $\mathrm{~T}$ \\
\hline 2008 & 8,72 & Ty & 19,06 & Ty & 64 & $\mathrm{~T}$ & 154 & $\mathrm{~L}$ & 84 & $S$ & 64 & $\mathrm{~T}$ \\
\hline 2009 & 7,68 & $\mathrm{St}$ & 20,46 & $\mathrm{St}$ & 80 & $\mathrm{~T}$ & 87 & $S$ & 156 & $\mathrm{~L}$ & 42 & $\mathrm{~S}$ \\
\hline 2010 & 2,89 & $\mathrm{St}$ & 18,50 & We & 117 & $\mathrm{~L}$ & 131 & $\mathrm{~T}$ & 62 & $\mathrm{~S}$ & 55 & $\mathrm{~S}$ \\
\hline 2011 & 6,98 & St & 18,97 & Ty & 122 & $\mathrm{~L}$ & 120 & $S$ & 80 & $S$ & 43 & $\mathrm{~S}$ \\
\hline 2012 & 6,72 & $\mathrm{St}$ & 20,73 & $\mathrm{St}$ & 100 & $\mathrm{~L}$ & 80 & $\mathrm{~S}$ & 141 & $\mathrm{~L}$ & 45 & $\mathrm{~S}$ \\
\hline 2013 & 9,85 & We & 20,17 & St & 35 & $\mathrm{~S}$ & 128 & $\mathrm{~T}$ & 136 & $\mathrm{~L}$ & 66 & $\mathrm{~T}$ \\
\hline $2014 *$ & 10,79 & $\mathrm{We}$ & 20,33 & St & & & & & & & & \\
\hline 2015 & 6,91 & $\mathrm{St}$ & 20,78 & St & 82 & $\mathrm{~T}$ & 89 & $S$ & 160 & $\mathrm{~L}$ & 34 & $\mathrm{~S}$ \\
\hline $\mathrm{n}$ & 44 & & 44 & & 29 & & 29 & & 29 & & 29 & \\
\hline AVR & 8,53 & & 18,91 & & 72,86 & & 131,72 & & 98,10 & & 62,55 & \\
\hline SD & 2,03 & & 1,07 & & 30,13 & & 27,44 & & 31,12 & & 16,69 & \\
\hline $\mathrm{CL}$ & $7,93-$ & & $18,60-$ & & $61,90-$ & & $121,74-$ & & $86,77-$ & & $56,48-$ & \\
\hline & 9,13 & & 19,23 & & 83,83 & & 141,71 & & 159,43 & & 68,63 & \\
\hline
\end{tabular}

\footnotetext{
* Year excluded from the season duration analysis;

We: weak intensity; St: strong intensity; Ty: typical intensity; S: short duration; L: long duration; T: typical duration n: sample size; AVR: average; SD: standard deviation; CL: confidence limits $(\alpha=0,05)$
} 


\section{Discussions}

Contributing to standardize in the hydrological periods delimitation, this study expands the procedure described by Bittencourt \& Amadio (2007) and demonstrate how a simple data collection can provide reliable models (see Equations 1 and 2) to identify the seasonal changes in a lake without any hydrometric history (see Tables 3, 4 and 5). We believe this approach can be especially useful for floodplain studies, due the flood pulse social and ecological importance (Poff et al., 1997; Bayley, 1995; Johnson, Richardson \& Naimo, 1995; Junk \& Wantzen, 2004; Alho, 2008; Lopes \& Caliman, 2008; Almeida et al., 2014; Soares, Freitas \& Oliveira, 2014) combined with the lack of permanent hydrometric monitoring programs in most of these environments (Ramalho et al., 2005).

Regarding the asymmetry of some distributions (see Figures 1 and 2), as the range of the data history increases, future studies may generate more precise estimations. In comparison, the data set used in this study, of 44 years, have less than a half of the range used by Bittencourt \& Amadio (2007), that was 101 years. Nevertheless, we cannot rule out the possibility that there is a real asymmetry in these distributions, either due to natural phenomena or climate changes (Cunico, Graça, Veríssimo \& Bini, 2002; Bonnet et al., 2008; Ramalho et al., 2005; Araujo \& Rocha, 2010; Freitas et al., 2012; Sousa \& Rocha, 2015; Ropke et al., 2017). In example, the Mamirauá lake hydrometric history, presented by Ramalho et al. (2005), also shows a slight increase in the maximum water level along 1990 to 2009, 19 years, which is expected to cause a negative skewness in the frequency distribution of maximum annual water level.

Concerning the differences between the lakes and the river seasons (see Figure 4 and Table 5), this is not uncommon phenomena. In fact, beside the distance, its usually associated with the environments connectivity (Centofante \& Melo, 2012; Brito, Alves \& Espirito-Santo, 2014), an important feature for its ecology and biodiversity (Freitas \& Sousa, 2004; Fantin-Cruz, Loverde-Oliveira \& Girard, 2008; Hurd et al., 2016). In example, the isolated Camaleão lake, located inside the Marchantaria Island, Amazonas state, has a fluctuating water level which follows the Solimões river from Rising to Receding and stabilizes during Low water season despite a severe reduction in the river level (Kreibich, 2002). Close to Camaleão, the Catalão lake is connected to both Negro and Solimões rivers, from the north and the south respectively, receiving more limnological influence of the first during Rising and of the last during High water season (Brito, Alves \& Espírito-Santo, 2014), meaning a different level of connectivity between them.

The Grande lacustric complex, where Jaitêua and São Lourenço lakes are located, is believed to be originated by the damming of the Manacapuru river with sediments carried by the Solimões river. This process normally is associated with the genesis of elongated dendritic lakes (Esteves, 2011b), a geomorphological class with remarkable productivity (Souza, 2000). As these floodplain lakes are subject to structural changes over time, we suspect the depth might not be the best measure for this kind of study. In example, Almeida et al. (2014), studying mercury contamination in Puruzinho lake, mentions the transport of this substance through sediments suspension and deposition. Thus, we believe a fixed staff gauge could prevent errors from sediments accumulation and bottom depth changes, generating more accurate results.

\section{Conclusions}

We extend the methodology proposed by Bittencourt \& Amadio (2007) to the lakes, where normally there are no hydrometric monitoring, and demonstrated how to delimit a lake hydrological seasons by correlating its depth, collected in a short period of months, with the main river water levels, provided there is a hydrometric history dataset available. In the process, we also spotted differences between the Solimões river hydrological seasons and Jaitêua and São Lourenço lakes.

\section{Aknowledgments}

Jaetêua and São Lourenço lakes depths are stored in the database of the Project entitled "Biology and ecology of floodplain lake fishes: subsidies for conservation and use of fish resources in the Amazon".

\section{References}

Alho, C. J. R. (2008). The value of biodiversity. Brazilian Journal of Biology, 68(4):1115-1118.

Almeida, R., Bernardi, J. V. E., Oliveira, R. C., Carvalho, D. P., Manzatto, A. G., Lacerda, L. D., \& Bastos, W. R. (2014). Flood pulse and spatial dynamics of mercury in sediments in Puruzinho lake, Brazilian Amazon. Acta Amazonica, 44(1):99-105. 
Acta of Fisheries and Aquatic Resources

Araujo, A. P. \& Rocha, P. C. (2010). Regime de fluxo e alterações hidrológicas no Rio Tibagi, Bacia do Rio Paranapanema, Alto Paraná. Revista de Geografia, 27(3).

Bayley, P. B. (1995). Understanding large river-floodplain ecosystems: significant economic advantages and increased biodiversity and stability would result from restoration of impaired systems. BioScience, 45(3):153-158.

Bittencourt, M. M. \& Amadio, S. A. (2007). Proposta para identificação rápida dos períodos hidrológicos em áreas de várzea do rio Solimões-Amazonas nas proximidades de Manaus. Acta Amazonica, 37(2):303308.

Bonnet, M.-P., Barroux, G., Martinez, J. M., Seyler, F., Moreira-Turcq, P., Cochonneau, G., Melack, J. M., Boaventura, G., Maurice-Bourgoin, L., Leon, J. G., Roux, E., Calmant, S., Kosuth, P., Guyot, J. L., \& Seyler, P. (2008). Floodplain hydrology in an Amazon floodplain lake (Lago Grande de Curuaí). Journal of Hydrology, 349(1/2):18-30.

Brito, J. G., Alves, L. F., \& Espirito-Santo, H. M. V. (2014). Seasonal and spatial variations in limnological conditions of a floodplain lake (Lake Catalão) connected to both the Solimões and Negro Rivers, Central Amazonia. Acta Amazonica, 44(1):121-134.

Centofante, E. \& Melo, C. E. (2012). Estrutura e composição da ictiofauna em um lago isolado na planície do médio rio Araguaia, Mato Grosso - Brasil. Biotemas, 25(3):173-186.

Cunico, A. M., Graça, W. J., Verissimo, S., \& Bini, L. M. (2002). Influência do nível hidrológico sobre a assembléia de peixes em lagoa sazonalmente isolada da planície de inundação do alto rio Paraná. Acta Scientiarum. Biological Sciences, 24(2):383-389.

Esteves, F. A. (2011a). Fundamentos de Limnologia, $3^{\text {a }}$ ed. Interciência: Rio de Janeiro,

Esteves, F. A. (2011b). Gênese dos ecossistemas lacustres. In Fundamentos de Limnologia, chapter 5, page 83-112. Rio de Janeiro: Interciência.

Fantin-Cruz, I., Loverde-Oliveira, S., \& Girard, P. (2008). Caracterização morfométrica e suas implicações na limnologia de lagos do Pantanal Norte. Acta Scientiarum. Biological Sciences, 30(2):133-140.

Freitas, C. E. C., Rivas, A. A. F., Campos, C. P., Sant'Ana, I., Kahn, J. R., Correa, M. A. A., \& Catarino, M. F. (2012). The potential impacts of global climatic changes and dams on amazonian fish and their fisheries. In Turker, H., editor, New advances and contributions to fish biology, chapter 5, page 175-195. InTech, [S.1.].

Freitas, C. E. C. \& Sousa, R. G. C. (2004). Comunidades de peixes dos canais naturais entre os lagos de várzea e o rio Solimões-Amazonas (Amazonas-Brasil). Acta Limnologica Brasiliensia, 16(3):273-280.

Hoffmann, R. (2016). Análise estatística de relações lineares e não lineares. Piracicaba.

Hurd, L. E., Sousa, R. G. C., Siqueira-Souza, F. K., Cooper, G. J., Kahn, J. R., \& Freitas, C. E. C. (2016). Amazon floodplain fish communities: habitat connectivity and conservation in a rapidly deteriorating environment. Biological Conservation, 195:118-127.

Isaac, V. J., Fabre, N. N., Silva, C. O., Ruffino, M. L., \& Saint-Paul, U. (2012). Ecologia da fauna ictiica. In Batista, V. S. and Isaac, V. J., editors, Peixes e pesca no Solimões-Amazonas: uma visão integrada, chapter 7, page 207-249. Ibama/ProVárzea, Brasília.

Johnson, B. L., Richardson, W. B., \& Naimo, T. J. (1995). Past, present, and future concepts in large river ecology: how rivers function and how human activities influence river processes. BioScience, 45(3):134.

Junk, W. J. \& Wantzen, K. M. (2004). The flood pulse concept: new aspects, approaches and applications an update. In Proceedings of the Second International Symposium on the Management of Large Rivers for Fisheries, page 117-140, Bangkok. FAO Regional Office for Asia and the Pacific; RAP Publication.

Kreibich, H. (2002). $\mathrm{N}^{2}$ fixation and denitrification in a floodplain forest in Central Amazonia, Brazil. Master's thesis, Philipps-Universität, Marburg.

Lopes, P. M. \& Caliman, A. (2008). A contribuição de ecossistemas lênticos para o entendimento da importância de processos regionais e locais sobre padrões geográficos de biodiversidade. Limnotemas, 6.

Maciel, H. M. (2010). Reprodução de espécies de peixes em lago de várzea, Manacapuru-AM. Master's thesis, Universidade Federal do Amazonas, Manaus.

Maciel, H. M., Soares, M. G. M., \& Prestes, L. (2011). Reprodução da piranha-amarela Serrasalmus spilopleura Kner, 1858, em lagos de várzea, Amazonas, Brasil. Biota Neotropica, 11(2):1-6.

Merona, B. \& Gascuel, D. (1993). The effects of flood regime and fishing effort on the overall abundance of an exploited fish community in the Amazon floodplain. Aquatic Living Resources, 6(2):97-108.

Nelder, J. A. \& Wedderburn, R. W. M. (1972). Generalized linear models. Journal of the Royal Statistical Society. Series A (General), 135(3):370-384.

Noughabi, H. A. \& Arghami, N. R. (2011). Monte Carlo comparison of seven normality tests. Journal of Statistical Computation and Simulation, 81(8):965-972. 
Acta of Fisheries and Aquatic Resources

Poff, N. L., Allan, J. D., Bain, M. B., Karr, J. R., Prestegaard, K. L., Richter, B. D., Sparks, R. E., \&

Stromberg, J. C. (1997). The natural flow regime: a paradigm for river conservation and restoration. BioScience, 47(11):769-784.

R Core Team (2017). $R$ : a language and environment for statistical computing. R Foundation for Statistical Computing, Vienna, Austria.

Ramalho, E. E., Macedo, J., Vieira, T. M., Valsecchi, J., Calvimontes, J., Marmontel, M., \& Queiroz, H. L. (2005). Ciclo hidrológico nos ambientes de várzea da reserva de desenvolvimento sustentável Mamirauá Médio Rio Solimões, período de 1990 a 2008. Uakari, 5(1):61-87.

Ropke, C. P., Amadio, S. A., Zuanon, J. A. S., Ferreira, E. J. G., Deus, C. P., Pires, T. H. S., \& Winemiller, K. O. (2017). Simultaneous abrupt shifts in hydrology and fish assemblage structure in a floodplain lake in the central Amazon. Scientific Reports, 7(40-70).

Saint-Paul, U., Zuanon, J. A. S., Villacorta-Correa, M. A., Garcia, M., Fabre, N. N., Berger, U., \& Junk, W. J. (2000). Fish communities in central Amazonian white- and blackwater floodplains. Environmental Biology of Fishes, 57(3):235-250.

Santos, R. N., Ferreira, E. J. G., \& Amadio, S. A. (2008). Effect of seasonality and trophic group on energy acquisition in Amazonian fish. Ecology of Freshwater Fish, 17(2):340-348.

Soares, M. G. M., Freitas, C. E. C., \& Oliveira, A. C. B. (2014). Assembleias de peixes associadas aos bancos de macrófitas aquáticas em lagos manejados da Amazônia Central, Amazonas, Brasil. Acta Amazonica, 44(1):143-152.

Sousa, R. V. B. \& Rocha, P. C. (2015). Identificação de períodos hidrológicos por meio de estatística descritiva e dos testes não paramétricos de Pettitt e Mann-Kenndall. Geosaberes, 6(2):113-129.

Souza, K. N. S. (2000). O rendimento pesqueiro em sistemas lacustres da Amazônia Central. Master's thesis, Instituto Nacional de Pesquisas da Amazônia; Universidade Federal do Amazonas, Manaus.

Winemiller, K. O. and Jepsen, D. B. (1998). Effects of seasonality and fish movement on tropical river food webs. Journal of Fish Biology, 53:267-296.

Yap, B. W. \& Sim, C. H. (2011). Comparisons of various types of normality tests. Journal of Statistical Computation and Simulation, 81(12):2141-2155. 